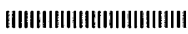

論文

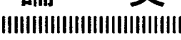

\title{
衣料新商品の普及。衰退過程の解析
}

（第 2 報）購入された衣料が逐次廃棄される場合

田畑昌 顕

\section{Diffusion Process of New Products of Clothing}

\section{Part 2 : On the Case of New Poducts Abandoned Successively}

\author{
Masaaki Tabata
}

\begin{abstract}
(1) Diffusion process of the new clothing products was mathematically analysed, in the case that the new products are abandoned successively.

In order to simplify analysis, five models were settled in connection with the manner in which the new products were abandoned.

(2) Equations expressing $N(t) / M, F(t) / M$ and $G(t) / M$ were derived in the five models respectively. Here $N$ $(t) / M$ shows the value of diffusion rate at time t. $F(t) / M$ and $G(t) / M$ are the relative values of the number of people who have bought and abandoned the new products in unit time at time $t$.

Shape of $N(t) / M, F(t) / M$ and $G(t) / M$ curves varies by the values of coefficient $\alpha, \beta$, q and r. Here $\alpha$ and $\beta$ are the coefficients related to the probability with which the people buy or abandone the product in unit time at time t. The symbol q shows the time when the abandonment of the products occurs, and $r$ shows the possessing period of the product.

By means of analysing these equations, we can understand the characteristics of the diffusion processes of the new products.

(3) Model A and B are the cases in that the people who have abandoned the products are expected to buy again them. In these models the value of $N(t) / M$ converges to a certain value after long period. Necessaries of life are the products of these models.

Model C, D and E are the cases in that the people who have abandoned the products will never buy them again. In these models, $N(t) / M$ forms a hill-shaped curve and its value reaches to zero after some period. Fashion clothings are the products of these models.
\end{abstract}

(Received March 16, 1998)

(Accepted for Publication Sept. 4, 1998)

\section{1. 緒 言}

本研究は衣料新商品が発売後どのように普及し衰 退していくか, その変化の基本的な性格を把握する ことを目的として, 衣料新商品の普及・衰退過程を 数式で表現しょうと試みたものである. 普及・衰退 過程の大筋を把握するため, 要因は極力単純化し た．消費者の購入・廃棄に関する個人差などの影響
については，これらの要因と数式中の係数との関係 を検討することにより考察できると考えている. 前報1では購入された新商品が廃棄されることな く継続して使用される場合について, 新商品が普及 していく過程を解析した．消費者が衣料新商品の購 入を決める確率は, その時点におけるその商品の使 用者の数に比例すると仮定している. その結果, 単 位時間当たり購入者数の時間的変化を表す関数 $F$

会員, Member, 大阪成蹊女子短期大学, Osaka Seikei Women's College, 大阪市東淀川区相川, Aikawa, Higasiyodogawa-ku, Osaka 
（t） および普及率の時間的変化を表す関数 $N(t)$ を 数式として導くことができた。 これによれば $F(t)$ は正規分布に類似する曲線で表され， $N(t)$ はロジ スティック曲線といわれる $S$ 字型の曲線で表され ることがわかった。

しかし購入された商品がまったく廃棄されないと いう仮定は現実的ではない，そこで本報では購入さ れた商品が逐次廃棄されていく過程を 5 種類のモデ ルで表し，それぞれのモデルについてこの商品に関 する $N(t), F(t)$ および単位時間当たり廃棄者数の 時間的変化を示す関数 $G(t)$ を導いた。そしてこれ らの数式を検討することにより，その普及・衰退過 程の特徵を把握しょうと試みた。

\section{2. モデルの設定}

\section{1 商品所有者の廃棄行動}

商品所有者の廃棄行動すなわち商品の廃棄のされ 方については，その代表的なタイプとして次の諸ケ ースが考えられる.

(1) すでに購入使用されている商品を污損等の理 由で廃棄したときに，直ちに代わりの新品を購入す るケース。このケースでは商品が廃棄されると，ほ ぼ同時に購入が行われる，必需的消耗品がこのケー スに当てはまる.

（2）最初購入した商品を不要と考え一旦廃棄した が, しばらくたってまた必要となり，再度この商品 を購入するケース．このケースでは販売開始直後か ら商品の廃棄が始まるが, 最初に購入した商品を廃 裹した時点から 2 度目の商品を購入する時点までの 時間には，人によりかなりばらつきがある，必需品 ではないが必需品に近い商品の場合に多い.

（3）販売開始直後から商品の廃棄が始まるが，一 旦廃衰した後は, 再度この商品を購入することはな いケース. 必需品ではなく, かつ商品価値に問題が あるような流行商品に起こりやすいと思われる.

(4) 販売開始後ある時間（流行期間に相当する） が経過してから廃衰が始まるケース，廃棄する時期 については所有者によりばらつきがある. 流行期間 が過ぎると商品価值が下がり, 使用頻度が急激に低 下する一般の流行商品がこれに当てはまる．このケ 一スでは一度廃棄した人はこの商品を再び購入する ことはないと考えられる。

(5) 購入された商品は長期間使用された後廃棄さ れるが, 保有期間はその商品の本来の耐用年数に近
く, 所有者によるばらつきが比較的小さいケース. デザインや品質が優れた商品価值の高い商品はその 一例であろう。この場合む一旦商品を廃棄した人が 再度この商品を購入する可能性はない。

\section{2 モデルの設定}

前項において商品所有者の廃棄行動に関し 5 種類 のケースを考えたが, これらの5ケースのそれぞれ に対応し, 次の 5 モデル A, B， C, D, E を設定す る.なお前報のケース, すなわち購入された商品が 廃棄されず継続して使用される場合を基本モデルと よぶことにする。

（1）基本モデル：前報で用いたモデルである．購 入された商品は廃棄されることなく, 長期間継続し て使用される。単位時間内に未購入者が新商品を購 入する確率は, その時点における既購入者（所有者） の数に比例すると考える.

(2) モデル A：2.1項(1)のケースに対応する.こ のモデルでは, すでに購入所有されている商品が污 損などの理由で廃棄されると, 直ちに代わりの新品 が購入されると考える. 廃棄と代品の購入が同時で ある。

(3) モデル B：2.1項(2)のケースに対応する.こ のモデルでは, 購入された商品は発売開始直後から 時間の経過に伴い，一定の確率で逐次廃棄されてい くが，一旦廃裹した人あ廃衰後しばらくたってから 再び新品を購入する可能性があると考える.

(4) モデルC：2.1項(3)のケースに対応する.こ のモデルでは, 購入された商品は販売開始直後から 一定の確率で逐次廃棄されていくが, 一旦廃棄した 人は以後この商品を購入する可能性がないと考え る. 再度この商品を購入する可能性がない点が, モ デル. B と異なっている.

(5) モデル D : 2.1項(4)のケースに対応する.こ のモデルでは, 購入された商品は発売当初しばらく は廃衰されず, 発売後時間 $\mathrm{q}$ が経過した時点から一 定の確率で廃棄されていく．また一旦廃棄した人は 以後この商品を購入しないと考える.

(6)モデル E：2.1項(5)のケースに対応する．この モデルでは, 商品は購入後一定期間 $\mathrm{r}$ だけ保有使用 された後に廃棄され，かつ一旦廃棄した人は以後こ の商品を睡入しないと考える. モデル D では商品の 保有使用期間は所有者によって異なり一定ではない が，モデル E では商品の保有使用期間はすべての所 有者について一定であるとする. 
モデル A と B では一度廃棄した人も再度この商 品を購入する可能性があるが, モデル C, D, Eでは 一度廃棄した人は再度この商品を購入する可能性は ない.

なお 1 人が 1 回に購入する商品数は全モデルにお いて1っとする.

\section{3. 理論式と考察}

\section{1 記 号}

記号を前報と同様次のように定める.

$$
t
$$

: 時間. 単位は年, 月あるいは日など 適宜定めることができるが，本報で は便宜上時間の単位を TUで表す ことにする：単位が変われば係数 $\alpha, \beta$ の値む変わってくる.

$N(t) \quad$ : 時刻 $t$ においてこの商品を所有して いる人の数

$F(t) \quad$ : 時刻 $t$ において単位時間内にこの商 品を購入する人の数

$G(t) \quad$ : 時刻 $t$ において単位時間内にこの商 品を廃棄する人の数

$M \quad$ ：この商品の購入使用が期待される層 に属する人の総数

$N_{0}=N(O)$ : 時刻 $\mathrm{t}=\mathrm{O}$ においてこの商品を所有 している人の数

以上のように定義すると次式が成り立つ（図 1 参 照).

$$
\begin{aligned}
& N(t)=N_{o}+\int_{o}^{t} F(t) d t-\int_{o}^{t} G(t) d t \\
& d N(t) / d t=F(t)-G(t)
\end{aligned}
$$

\section{2 基本モデルの場合}

基本モデルでは常に $G(t)=0$ である. そして前報

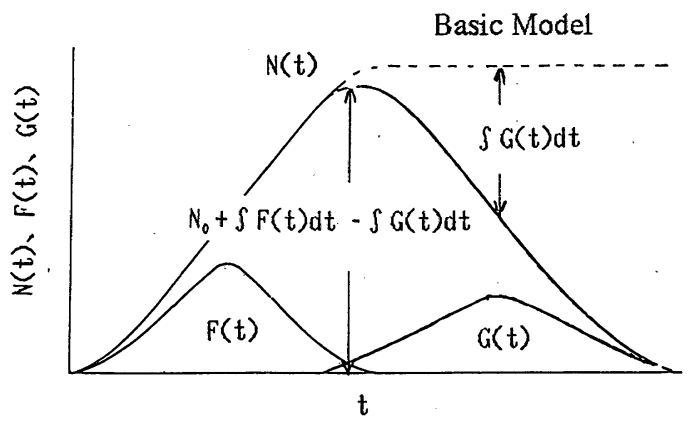

Fig 1 Relation between $N(t) / M, F(t) / M$ and $G$ $(\mathrm{t}) / \mathrm{M}$
で述べたように, 非所有者（未購入者）が単位時間 内に新商品を購入する確率は，その時刻 $t$ における 所有者数 $N(t)$ に比例する. したがって時刻 $t$ と $t+$ $\Delta t$ 間で非所有者がこの商品を購入する確率は $\alpha N$ $(t) \Delta t$ で表すことができる. ここで $\alpha$ は，この商品 の所有者が非所有者の購買意欲に与える影響の大き さを示す係数である．また時刻 $t$ における非所有者 の数は $\{M-N(t)\}$ であるから, 時刻 $t$ と $t+\Delta t$ 間で この商品を購入する人の数 $F(t) \Delta t$ は $\{M-N(t)\}$ と $\alpha N(t) \Delta t$ との積に等しい. この関係を(2)式に代入 し, かつ $G(t)=0$ とおくと, 前報で述べたように次 式が成立する.

$$
F(t)=d N(t) / d t=\alpha N(t)\{M-N(t)\}
$$

(3)式を解けば

$$
\frac{N(t)}{M}=\frac{1}{1+k \exp (-\alpha M t)}
$$

(4)式を(3)式に代入し

$$
\begin{aligned}
\frac{F(t)}{M} & =\alpha M\left\{\frac{1}{1+k \exp (-\alpha M t)}\right\} \\
& \times\left\{1-\frac{1}{1+k \exp (-\alpha M t)}\right\}
\end{aligned}
$$

ただし $\mathrm{k}$ は $\mathrm{K}=M / N_{0}-1$ より求められる数値で ある.

\section{3 モテル A の場合}

このモデルでは, 時刻 $t$ と $t+\Delta t$ 間でこの商品を 購入する人の数 $F(t) \Delta t$ は，この間にこの商品の使 用者から刺激を受けて, 初めてこの商品を購入する 人の数 $F_{1}(t) \Delta t$ 之, 污損した商品を廃棄して代わり に新品を購入する人の数 $F_{2}(t) \Delta t$ の和として与えら れる.よって(2)式は次式のように書ける.

$$
d N(t) / d t=F_{1}(t)+F_{2}(t)-G(t)
$$

このモデルでは廃棄と同時に新品が購入されるか ら, $F_{2}(t) \Delta t$ は時刻 $t$ と $t+\Delta t$ 間でこの商品を廃棄す る人の数 $G(t) \Delta t$ に等しいはずである. よって $(6)$ 式 で $F_{2}(t)=G(t)$ とおけば

$$
d N(t) / d t=F_{l}(t)
$$

一方, $F_{1}(t) \Delta t$ は前述の基本モデルと同様 $\alpha N(t)$ $\Delta t$ と $\{M-N(t)\}$ の積で与えられるから,これを $\left(6^{\prime}\right)$ 式に代入すれば次式が成立する.

$$
d N(t) / d t=\alpha N(t)\{M-N(t)\}
$$

この式は(3)式とまったく同じであり，したがって モデル A における $N(t), F(t)$ は基本モデルと同様 (4)および(5)式で与えられる.これらの式は廃棄と購 入が何回繰り返されてあ, それが同時に行われる限 


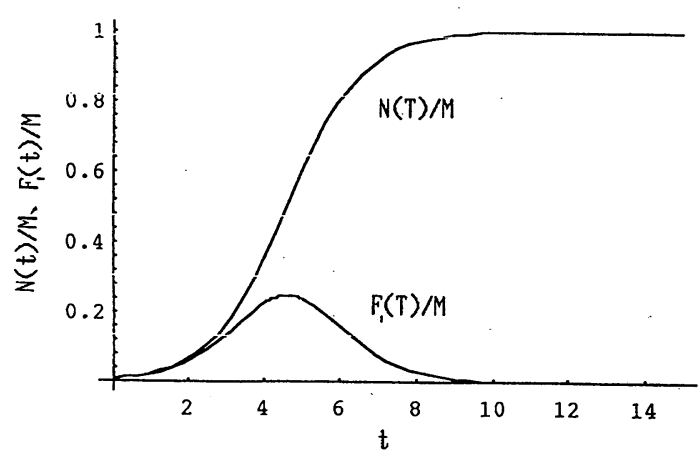

Fig $2 \mathrm{~N}(\mathrm{t}) / \mathrm{M}$ and $\mathrm{F}(\mathrm{t}) / \mathrm{M}$ in the case of Model $\mathrm{A}$ $(\alpha M=1.0, k=99)$

り成立する。

なお, $G(t)$ は種々の場合が考えられ, 特定の数式 として表すことはできない，また基本モデルの場合 と異なり，モデル A の場合には所有者数と商品の 販売数量とは一致しない。

図 2 にモデル A における $N(t) / \mathrm{M}, \mathrm{F}_{1}(\mathrm{t}) / \mathrm{M}$ の値 と時刻 $t$ との関係の一例を示す。 $\alpha M=1.0, \mathrm{k}=99$ $\left(N_{a} / M=0.01\right)$ として計算した. ただし $F_{2}(t)$ およ び $G(t)$ は確定した数式として表すことができない ので，その記入は省略した。

\section{4 モデル B の場合}

購入された商品は販売開始直後から逐次廃棄され ていくが，廃棄行動に関しては対象とする層の消費 者はすべて同質であり，単位時間当たりの廃棄者数 $G(t)$ は所有者数 $N(t)$ に常に比例すると考える. し たがって, この比例常数を $\beta$ 'とおけば, 時刻 $t$ と $t$ $+\Delta t$ 間でこの商品を廃棄する人の数 $G(t) \Delta t$ は次式 で与えられる.

$$
G(t) \Delta t=\beta^{\prime} N(t) \Delta T
$$

$\beta$ 'の值は所有者が単位時間内にこの商品を廃棄す る確率を示し， $\beta$ が大きいほど，この商品は早く廃 棄されることになる.

(7)式で $\beta^{\prime}=\beta M$ とおけば， $G(t)$ は次のように書け る.

$$
G(t)=\beta M N(t) \text { または } G(t) / M=\beta M N(t) / M
$$

この商品の非所有者が時刻 $t$ と $t+\Delta t$ 間でこの商 品を購入する確率は $\alpha N(t) \Delta t$ である. 一方, 時刻 $t$ における非所有者の数は $\{M-N(t)\}$ で表されるか ら, 時刻 $t$ で単位時間内にこの商品を購入する人の 数 $F(t)$ は, 基本モデルと同様両者の積すなわち(3) 式で与えられる，よって(3)式と(8)式を(2)式に代入す
れば

$$
\begin{aligned}
d N(t) / d t & =\alpha N(t)\{M-N(t)\}-\beta M N(t) \\
& =N(t)\{(\alpha-\beta) M-\alpha N(t)\}
\end{aligned}
$$

(9)式は次式のように変形できる.

$$
\frac{d N(t)}{N(t)}+\frac{\alpha d N(t)}{(\alpha-\beta) M-\alpha N(t)}=(\alpha-\beta) M d t \quad(10)
$$

両辺を積分すれば

$$
\log N(t)-\log [(\alpha-\beta) M-\alpha N(t)]=(\alpha-\beta) M t+c
$$

左辺をまとめれば

$$
\begin{aligned}
& \log \left[\frac{N(t)}{(\alpha-\beta) M-\alpha N(t)}\right]=(\alpha-\beta) M t+c \\
\therefore & \frac{N(t)}{(\alpha-\beta) M-\alpha N(t)}=c^{\prime} \exp [(\alpha-\beta) M t]
\end{aligned}
$$

これより $N(t)$ を求めれば

$$
\begin{aligned}
& N(t)=\frac{(\alpha-\beta) M}{\alpha}\left\{\frac{1}{1+k \exp [-(\alpha-\beta) M t]}\right\} \\
\therefore & \frac{N(t)}{M}=\frac{(\alpha-\beta)}{\alpha}\left\{\frac{1}{1+k \exp [-(\alpha-\beta) M t]}\right\}
\end{aligned}
$$

ここで $\mathrm{c}, \mathrm{c}^{\prime}$ は積分常数, $\mathrm{k}$ は $\mathrm{k}=1 /\left(\mathrm{c}^{\prime} \alpha\right)$ である.

$\mathrm{N}(0)=\mathrm{N}_{0}$ であるから

$$
\begin{aligned}
& \mathrm{N}_{0} / \mathrm{M}=\{(\alpha-\beta) / \alpha\}\{1 /(1+\mathrm{k})\}=(1-\beta / \alpha) /(1+\mathrm{k}) \\
\therefore \mathrm{k} & =(1-\beta / \alpha)\left(\mathrm{M} / \mathrm{N}_{0}\right)-1
\end{aligned}
$$

また(14)式で $t=\infty$ とおくと

$$
N(\infty) / M=(\alpha-\beta) / \alpha=1-\beta / \alpha
$$

これによれば $\mathrm{t} \rightarrow \infty$ では, $\mathrm{N}(\mathrm{t}) / \mathrm{M}$ の值は $(1-\beta /$ $\alpha)$ に収斂することがわかる.ただし $\beta<\alpha$ とする(注 1).

$F(t) / M, G(t) / M$ は(3)，(8)式に(13)式を代入すれば 求められ

$$
\begin{aligned}
\frac{F(t)}{M} & =(\alpha-\beta) M\left\{\frac{1}{1+k \exp [-(\alpha-\beta) M t]}\right\} \\
& \times\left[1-\frac{(\alpha-\beta)}{\alpha}\left\{\frac{1}{1+k \exp [-(\alpha-\beta) M t]}\right\}\right] \\
\frac{G(t)}{M} & =\beta M \frac{(\alpha-\beta)}{\alpha}\left\{\frac{1}{1+k \exp [-(\alpha-\beta) M t]}\right\}
\end{aligned}
$$

モデル B における $N(t) / M, F(t) / M, G(t) / M$ の 值を(14)，(17)，(18)式より計算し，その結果の一例を図 3 に示す. ただし $\alpha M=1.0, \beta M=0.3, k=99$ として 計算した。 またこの場合の $N(\infty) / M$ の値を(16)式よ り求めると

$$
N(\infty) / M=1-\beta / \alpha=1-0.3 / 1.0=0.7
$$

すなわち, この場合には, $N(t) / M$ の值は $0.7 に$ 収 斂する.

このモデルでは図 3 の例が示すように, $F(t) / M$ 


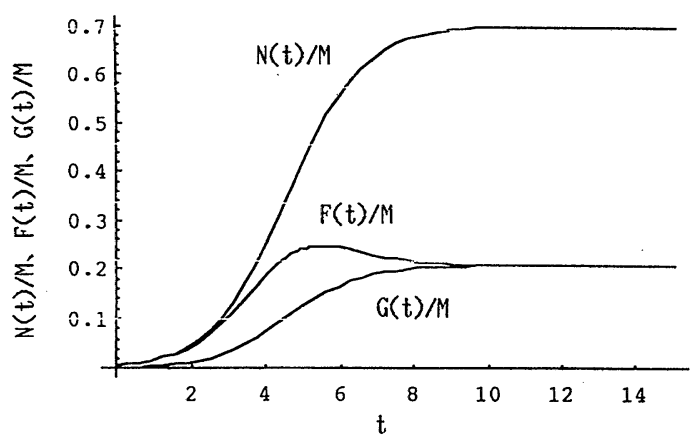

Fig $3 N(t) / M, F(t) / M$ and $G(t) / M$ in the case of Model B

$(\alpha M=1.0, \quad \beta M=0.3, \quad k=99)$

は一旦最大值をとった後減少し, 次第に $G(t) / M$ の 值に近づいていく．そしてある時点から $F(t) / M$ と $G(t) / M$ が等しくなって $N(t) / M$ の值は安定し, 1 より小さい值 $(1-\beta / \alpha)$ に収斂するようになる．た だし実際の場合には $F(t) / M$ と $G(t) / M$ の值が等し い状態が長期間維持されるとは限らない，その場合 には $N(t) / M$ は一定值をとらず， $(1-\beta / \alpha)$ を中心 としてその上下に波状に変動するようになる.

$\mathrm{Modis}^{2)}$ のいうカオスとはこのような状態を指すの であろう.また長時間経過後では総数 $M$ 人のうち 常時 $M \times \beta / \alpha$ 人がこの商品を所有していないこと になる．ただしこれらの人は特定の人達ではなく， 所有者之非所有者が始終入れ替わりながら，一定の 比率 $\beta / \alpha$ を保っているわけである. $(\beta / \alpha<1)$.

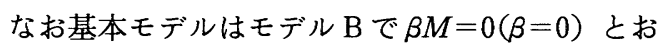
いた場合に相当する.

\section{5 モデルCの場合}

時刻 $t$ と $t+\Delta t$ 間で非所有者がこの商品を購入す る確率はモデル B と同様 $\alpha N(t) \Delta t$ であるが，モデ ル B と異なりモデル C では, 非所有者 $\{M-N(t)\}$ 人のうち，この商品をすでに廃棄した人はこの商品 をふたたび購入することはない．時刻 $t$ までにこの 商品を廃棄した人の数は $\int_{0}^{t} G(t) d t$ で与えられるか ら, 非所有者のうちこの商品を購入する可能性のあ る人の数は $\left\{M-N(t)-\int_{0}^{t} G(t) d t\right\}$ となる.

時刻 $t$ と $t+\Delta t$ 間でこの商品を購入する人の数 $F$ $(t) \Delta t$ は, 非所有者がこの商品を購入する確率 $\alpha N$ $(t) \Delta t$ 之購入の可能性のある非所有者の数との積に 等しいから, 次式が成立する.

$$
F(t) \Delta t=\alpha N(t)\left\{M-N(t)-\int_{o}^{t} G(t) d t\right\} \Delta t
$$

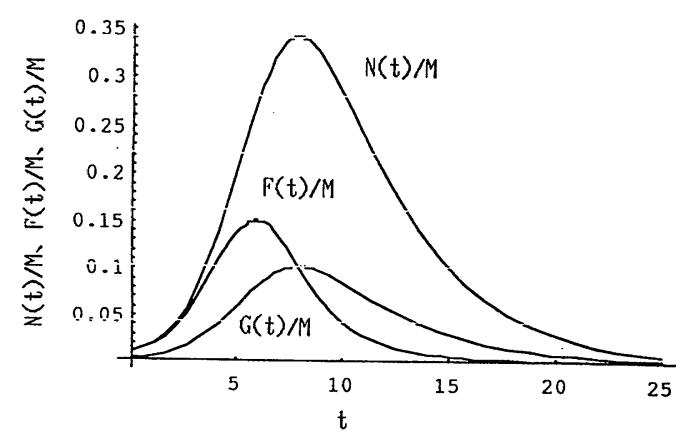

Fig $4 N(t) / M, F(t) / M$ and $G(t) / M$ in the case of Model C

$\left(\alpha M=1.0, \quad \beta M=0.3, \quad N_{o} / M=0.01\right)$

$$
\therefore F(t)=\alpha N(t)\left\{M-N(t)-\int_{0}^{t} G(t) d t\right\}
$$

(2)式に(19)式を代入すれば

$$
d N(t) / d t=\alpha N(t)\left\{M-N(t)-\int_{0}^{t} G(t) d t\right\}-G(t) \quad(20)
$$

一方, モデル B と同様, 時刻 $t$ と $t+\Delta t$ 間でこの 商品を廃棄する人の数 $G(t) \Delta t$ は(8)式で与えられ

る.よって(8)式を(20)式に代入すれば

$$
\begin{aligned}
d N(t) / d t & =\alpha N(t)\left\{M-N(t)-\beta M \int_{a}^{t} N(t) d t\right\}-\beta M N(t) \\
& =N(t)\left\{(\alpha-\beta) M-\alpha N(t)-\alpha \beta M \iint_{0}{ }_{0} N(t) d t\right\}
\end{aligned}
$$

微分方程式(21)を解けば $N(t)$ が数式として求めら れる.これと(19)および(8)式から $F(t)$ と $G(t)$ あ求め られるわけであるが，(21)式より $N(t)$ の一般式を導 くのは容易ではない. よって数值計算により $N(t) /$ $M, F(t) / M, G(t) / M$ の值を求めることにする. そ の結果の 1 例を図 4 に示した。ただし $\alpha M=1.0$,

$\beta M=0.3, N_{o} / M=0.01$ として計算した.

モデルCでは, 図 4 の例が示すように, $N(t) / M$ は $S$ 型ではなく, 山型の曲線を画く.すなわち, $N$ $(t) / M$ は発売後しばらくは増加する曲線を画くが, 最大值をとった後減少に転じ, 図 4 の例では $t=25$ TU 付近で, ほぼゼロとなり, この商品はこの時点 で消滅することがわかる，一方， $F(t) / M$ は $N(t) /$ $M$ の最大值よりあ早い時点で最大値をとり, $N(t) /$ $M$ よりあ早い時点でほぼゼ口となっている. また $G$ $(t) / M$ は(8)式が示すとおり, $N(t) / M$ を $\beta M$ 倍（こ の場合では 0.3 倍）した曲線となる.

係数 $\alpha$ と $\beta$ の值は $N(t) / M$ の形状に大きく影響 する.図 5 は $\alpha M=1.0$ および2.0, $\beta M=0.3$ おび 0.5 の場合について $N(t) / M$ の值を計算した結果を 示す.ただし，いずれす $N_{0} / M=0.01$ とした．これに よれば $\alpha M$ が1.0から2.0に増大することにより， $N$ $(t) / M$ が最大值をとる時期が早くなるとともに最 


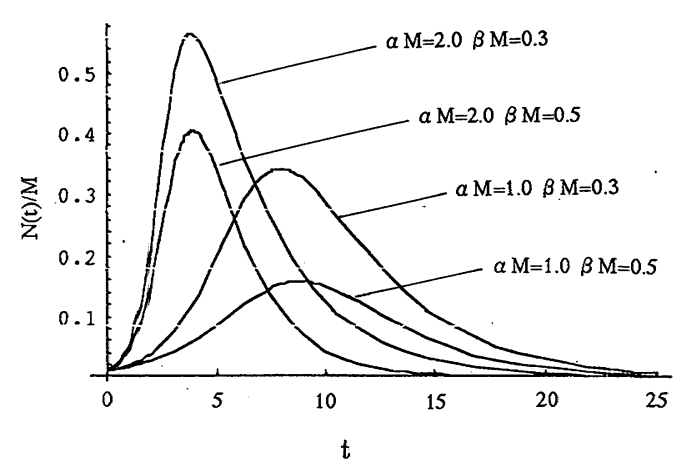

Fig 5 Influence of $\alpha \mathrm{M}$ and $\beta \mathrm{M}$ on $\mathrm{N}(\mathrm{t}) / \mathrm{M}$ in the case of Model C

大值あ大きくなること, また $\beta M$ が0.5から0.3に減 少することにより, $N(t) / M$ の最大值が大きくなる ことがわかる。なお $\beta M$ がさらに減少すると， $N$ $(t) / M$ 曲線は次第に基本モデルの $N(t) / M$ 曲線に 近づき, $\beta M=0$ ではこれに一致する. したがって $N$ $(t) / M$ 曲線が山型を作るためには， $\beta M$ はある程度 の大きさが必要である.

\section{6 モデル D の場合}

このモデルでは販売開始時刻 qTU までは購入さ

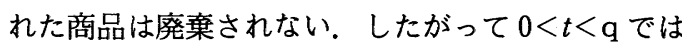
$G(t)=0$ である. よってこの範囲では $N(t), F(t)$ の 值は基本モデルとまったく同じである.

販売開始後 qTU たってから廃棄が始まり，その 後は一定の比率で廃棄されていくと仮定すると, 時 刻 qTU からはモデルC と同様となり, モデル Cで 導かれた数式を適用することができる.

したがって, q $\leqq t$ における $N(t) / M$ の值は(4)式 で $t=\mathrm{q}$ における $N(t)$ の值 $N(q)$ を求め, これを $N$ （t）の初期値として(21)式の解を計算した後, $t$ を $t+$ $q$ 之読み替えれば求めることができる. 図上では(21) 式により得られた曲線を時間 q だけ右方へ移動す ればよい。また $F(t), G(t)$ はモデル C の場合と同 様な方法で計算できる.このようにしてモデル D に おける $N(t) / M, F(t) / M, G(t) / M$ 曲線の值が求め られる。

これらの式を用いてモデル D における $N(t) / M$, $F(t) / M, G(t) / M$ の值を計算し, その結果の一例を 図 6 に示した。 ただし $\mathrm{q}=5 \mathrm{TU}, \alpha M=1.0, \beta M=$ $0.3, N_{0} / M=0.01$ として計算した.

$\mathrm{q}$ および $\beta M$ の值の影響を知るために, $\mathrm{q}=5,9$,

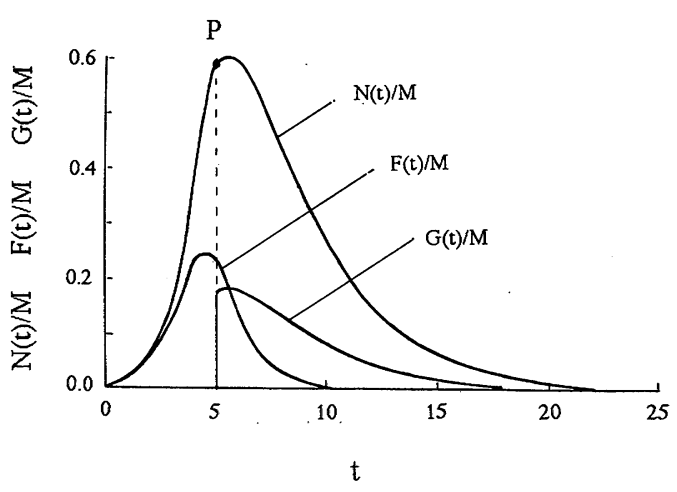

Fig $6 N(t) / M, F(t) / M$ and $G(t) / M$ in the case of Model D

$\left(q=5, \alpha M=1.0, \quad \beta M=0.3, \quad N_{\Omega} / M=0.01\right)$

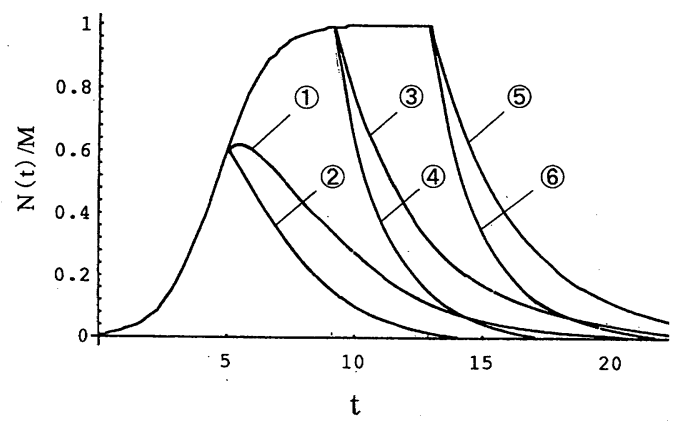

Fig 7 Influence of $q$ and $\beta \mathrm{M}$ on $\mathrm{N}(\mathrm{t}) / \mathrm{M}$ in the case of Model D

$\left(\alpha M=1.0, N_{\alpha} / M=0.01\right)$

(1) $q=5, \beta M=0.3 \quad$ (2) $q=5, \beta M=5 \quad$ (3) $q=$ $9, \beta M=0.3 \quad$ (4) $q=9, \beta M=0.5 \quad$ (5) $q=13$, $\beta M=0.3 \quad$ (6) $q=13, \beta M=0.5$

13TU，および $\beta M=0.3 ， 0.5$ の場合について $N(t) /$ $M$ の值を計算し, 図 7 に示した. q が大きくなるに したがい, $N(t) / M$ 曲線の頂部が基本モデルの $N$ $(t) / M$ 曲線にそいながら上方そして右方に移動す ることがわかる．また $\beta M$ の値の大きいほど衰退時 の曲線の勾配は急になることがわかる.

\section{7 モデルEの場合}

\subsection{1 $N(t), F(t), G(t)$ の関係}

このモデルでは, すべての所有者が商品購入後こ の商品を一定期間 rTU だけ保有（使用）した後廃棄 すると考える. したがって時刻 $t$ において購入され た商品は時刻 $t+r$ において必ず廃棄されることに なる.よって時刻 $t$ と $t+\Delta t$ 間でこの商品を購入し た人の数 $F(t) \Delta \mathrm{t}$ は, 時刻 $t+r$ と $t+r+\Delta t$ 間でこの 

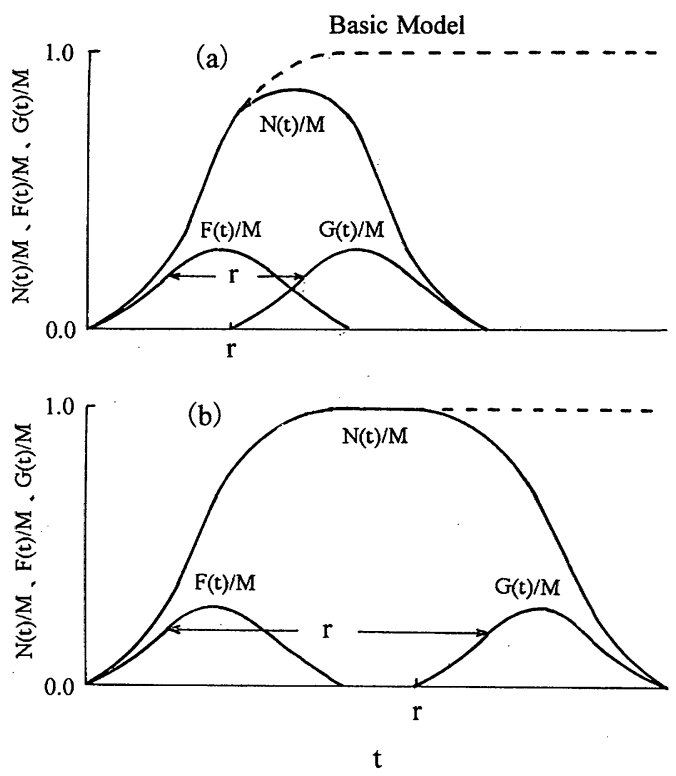

Fig 8 Diagram showing the relation between $\mathrm{N}$ $(\mathrm{t}) / \mathrm{M}, \mathrm{F}(\mathrm{t}) / \mathrm{M}, \mathrm{G}(\mathrm{t}) / \mathrm{M}$ and $\mathrm{r}$ in the case of Model $\mathrm{E}$

商品を廃棄した人の数 $G(t+r) \Delta t$ に等しいはずで ある. よって次の関係が成立する。

$$
F(t)=G(t+r) \quad \text { または } F(t-r)=G(t) \quad \text { (22) }
$$
この関係を図 8 に示す. 図からわかるように, $G$ $(t)$ は $F(t)$ を時間 $r$ だけ右側に並行移動した曲線と なる.

(1)式に(22)式を代入すれば次式が得られる.

$$
\begin{aligned}
N(t) & =N_{o}+\int_{o}^{t} F(t) d t-\int_{a}^{t} F(t-r) d t \\
& =N_{o}+\int_{o}^{t} F(t) d t-\int_{-r}^{t-r} F(t) d t \\
& =N_{0}+\int_{0}^{t} F(t) d t-\left\{\int_{-r}^{0} F(t) d t+\int_{0}^{t-r} F(t) d t\right\}
\end{aligned}
$$

$\int{ }_{-}^{0} F(t) d t$ は時刻 $t=0$ において, すでにこの商 品を購入所有している人の数を表すから $N_{0}$ に等し

い.よって(23)式は次式のようになる.

$$
\begin{aligned}
N(t) & =\int_{0}^{t} F(t) d t-\int_{0}^{t-r} F(t) d t \\
\therefore N(t) & =\int_{t-r}^{t} F(t) d t
\end{aligned}
$$

(24)式によれば $N(t)$ は $\int{ }_{0}^{t} F(t) d t$ と ${ }_{0}^{t-r} F(t) d t$ の 差に等しい，この関係を図 9(a)に示す。 また(25)式に よれば $N(t)$ は $F(t)$ を時刻 $(t-r)$ から $t$ まで積分 した值に等しい．この関係を図 $9(\mathrm{~b})$ に示す。これら の図からモデル $\mathrm{E}$ における $N(t) / M$ は，頂上部の 比較的なだらかな曲線を画くと推定される.

なお時刻が $r$ に達するまでは $G(t)=0$ であるか
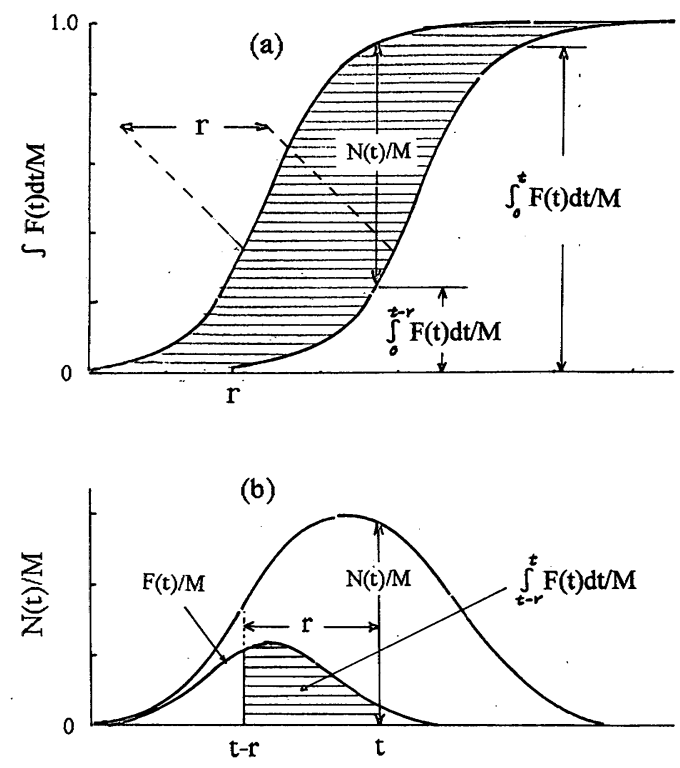

Fig 9 Relation between $N(t) / M$ and $\int F(t) d t / M$ in the case of Model $\mathrm{E}$

ら, $0<t<\mathrm{r}$ では $N(t) / M, F(t) / M$ の值は基本モデ ルとまったく同じである. したがって，rが十分に 大きければ図 8(b)に示すように, $N(t) / M$ は時刻 $\mathrm{r}$ に達する前に值 1 をとり，値 1 を維持した状態で時 刻 $r$ に達し，その後減衰して最後に 0 となる左右対 称の曲線を画くことになる．また $\mathrm{r}$ が比較的小さ く, $F(t) / M$ 曲線と $G(t) / M$ 曲線が重なる場合には, 図 8(a)が示すように $N(t) / M$ は 1 に達せず，両曲線 が交差する時点で 1 より小さい極大值をとる山型の 曲線となる。

\section{7 .2 連続関数で現した場合}

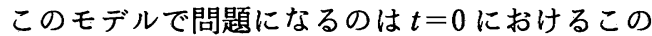
商品の所有者 $N_{0}$ 人に対する考え方である．すなわ ち(a) $N_{0}$ 人の人が $t=0$ において商品を瞬間的に購入 したと考えるか, あるいは(b)時刻 $t=0$ 以前に購入 した人の数が $N_{0}$ 人であったと考えるかである．本 報では前者のように考える. したがって $t=\mathrm{r}$ に達 した瞬間 $N_{0}$ 人が一斉に商品を廃棄することにな る.

(i) $0<t<\mathrm{r}$

このモデルでは発売開始時刻 $\mathrm{r}$ までは廃棄する人 はいない. したがって $0<t<\mathrm{r}$ では $G(t)=0$ であ る. よって基本モデルと全く同様になり，前述の(4), (5)，(8)式が適用できる. 


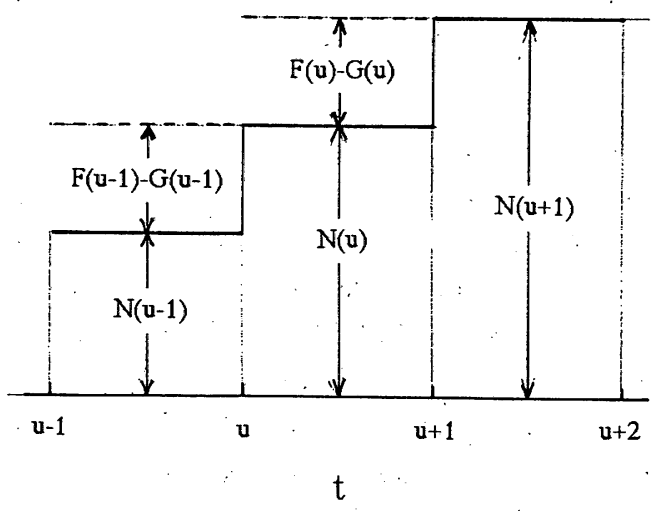

Fig 10 Relation between $\mathrm{N}(\mathrm{u}), \mathrm{F}(\mathrm{u})$ and $\mathrm{G}(\mathrm{u})$ in the discrete case of Model E

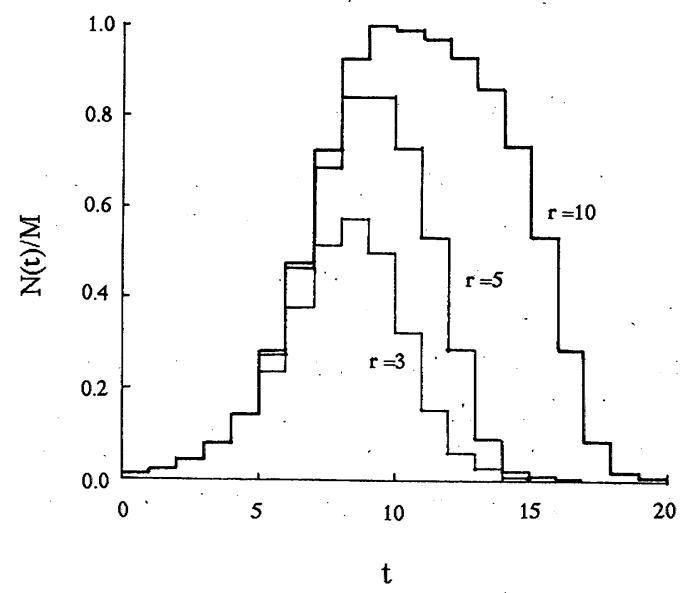

Fig $11 \mathrm{~N}(\mathrm{t}) / \mathrm{M}$ in the discrete case of Model $\mathrm{E}$ $\left(N_{\downarrow} / M=0.01, \quad \alpha \quad M=1.0, \quad r=3,5,10\right)$

(ii) $\mathrm{r}<t$

この領域では廃棄する人が現れる．このモデルで は，すでに商品を廃棄した人達は再度この商品を購 入することはない. よってモデル D と同様, $N(t)$ に関して前述の(20)式が成り立つ.したがって(20)式と (19), (22)式から， $N(t), F(t), G(t)$ が求められる.

\subsection{3 離散的関数で現した場合}

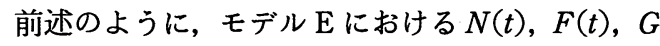
( $t$ ) は(20)式と(19), (22)式から求められるはずであるが, これらの連立方程式を解くことは極めて困難であ る. しかし $N(t), F(t), G(t)$ を離散的関数で表すこ とにより，その値を近似的に求めることができる.

図10に示すように, 新商品を所有する人の数は時 刻 $\mathrm{u}$ から時刻 $u+1$ の間では一定値 $N(u)$ を保つと する. 時刻が $u+1$ に達するとこの商品を新たに $F$

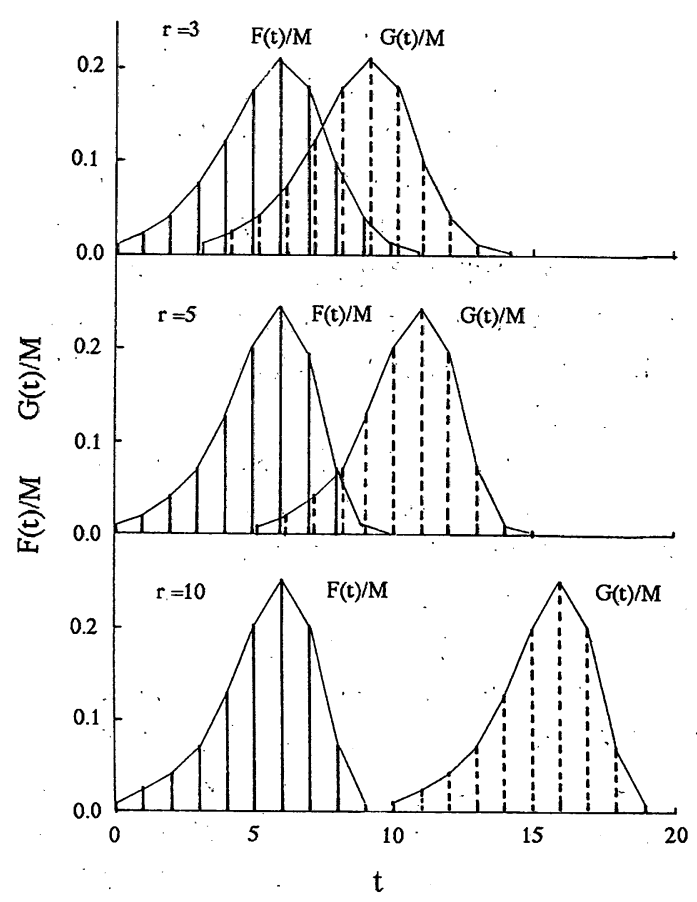

Fig $12 F(t) / M$ and $G(t) / M$ in the case of Figure 11

（u）人が購入し $G(u)$ 人が廃棄する. したがって時 刻 $u+1$ から時刻 $u+2$ の間でこの商品を所有する 人の数 $N(u+1)$ は次式で表される. ただし $u=0$,

$1,2,3,4$ ・・とする.

$$
N(u+1)=N(u)+F(u)-G(u)
$$

また $N(u), F(u), G(u)$ の間には, 次の関係が成 り立つ。

$$
\begin{aligned}
& F(u)=\alpha N(u)\left\{M-N(u)-\sum_{0}^{u-1} G(i)\right\} \\
& G(u)=F(u-r)
\end{aligned}
$$

(26), (27), (28)式より $N(u) / M, F(u) / M, G(u) / M$ の 值を計算することができる。 その結果の一例を図 11 と12に示す. ただし $N_{0} / \mathrm{M}=0.01, \alpha M=1.0, \mathrm{r}=3$; $5 ; 10$ とした. 図11によれば $r$ の増大にとあない, $N$ $(t) / M$ が最大值をとる時期は遅くなり, 最大值の値 は大きくなることがわかる，また $r=10$ の場合には $N(t) / M$ の最大値は 1 に達し, しばらくその値を維 持した後減少に転じることがわかる，なお，この時 間間隔を短くしていけば, $N(u) / M$ の值は(20)式の $N$ $(t) . / M$ の值に限りなく近づくはずである.

\section{4. まとめ}

（1）商品を一度廃棄した人が再びこの商品を買う 
可能性がある場合とない場合では, $N(t) / M$ 曲線の 形状は大きく異なる．前者（モデル A, B がこの夕 イプ）の場合では, $N(t) / M$ の値は長時間経過すれ ば一定值に収斂する．すなわちこのタイプでは $N$ $(t) / M$ 曲線は山型にはならない. 後者 (モデル $\mathrm{C}$, $\mathrm{D}, \mathrm{E}$ がこのタイプ）の場合には $N(t) / M$ 曲線は山 型となり，ある時間が経過すればゼロとなる。

(2) モデル A, B に属する商品では, 普及率 $N$ $(t) / M$ は最大值に達した後も需要が安定し, 長期間 その值を維持する.

モデル A は污損などの理由で商品を廃棄した後, 直ちに代わりの新品を購入するような場合に当ては まる. 必需的消耗品がその例である. このモデルで は, $N(t) / M$ は基本モデルと同じく(4)式で表され, $N(\infty) / M$ は 1 に収斂する（図 2).

モデル B は一度商品を廃棄した後，しばらくして 再びその商品が欲しくなるような商品に当てはま る.このモデルでは, $N(t) / M, F(t) / M, G(t) / M$ は (14), (17), (18)式で与えられる. $F(t) / M$ は当初 $G(t) / M$ よりあ大きい值をとるが, 次第に $G(t) / M$ の值に近 づいていく (図 3). そしてある時点から両者は等し くなり, $N(t) / M$ の值は安定し $(1-\beta / \alpha)$ に収斂す るようになる $(\beta<\alpha)$. なお実際には $F(t) / M$ と $G$ $(t) / M$ が等しくなる状況が長時間維持されるとは 限らない，その場合は $N(t) / M$ は $(1-\beta / \alpha)$ を中心 として，その上下に波状に変動するようになる.

(3) モデル C, D, E はライフサイクルが短く $N$ $(t) / M$ が山型の曲線となる商品に当てはまる. いわ ゆる流行商品がその例である.

モデルC は販売開始直後から廃棄が始まるよう な商品に当てはまる.このモデルの $N(t) / M$ は(21)式 で与えられ, 販売開始直後から基本モデルより小さ い値をとり，全体になだらかな山型を形成する（図 4, 5). その形状は係数 $\alpha M$ と $\beta M$ の值によって決 まってくる. $\alpha M$ の大きいほど $N(t) / M$ が最大値を とる時期は早く, 最大値は大きくなり，また $\beta M$ が 大きいほど $N(t) / M$ の最大值は小さくなる.

モデル D は流行期間が過ぎると途端にその価值 を失うような商品に当てはまる，このモデルでは， $N(t) / M$ は時刻が $q$ に達するまでは基本モデルと同 じ曲線を画くが， $q$ を過ぎると急激にその值を減少 する (図 6). $\mathrm{q}<t$ における $N(t) / M$ の值は(21)式によ って求めることができる. $q$ が大きくなると, $N(t) /$ $M$ 曲線の頂部は基本モデルの $N(t) / M$ 曲線にそっ て上方かつ右方に移動する（図 7).
モデル E はその本来の寿命がくるまで使用され るような商品に当てはまる.このモデルの $N(t) /$ $M, F(t) / M, G(t) / M$ は, $0<t<\mathrm{r}$ においては基本乇 デルと同じであるが， $\mathrm{r}<t$ においては(20)，(19)，(22)式 の解として与えられる.この解を一般式として表す ことは困難だが，これらの式によれば， $G(t) / M$ 曲

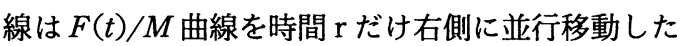
あのに一致する (図 8$)$. また $N(t) / M$ は頂部の比較 的なだらかな台形状の曲線を画くこと，また $r$ が大 きくなるほど $N(t) / M$ 曲線の高さは高くなり, かつ

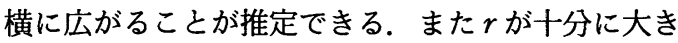
く, $F(t) / M$ と $G(t) / M$ 曲線が重ならない場合には, $N(t) / M$ は最大值 1 に達した後，しばらくその值を 維持すると推定される (図 8,9).これらの関係は離 散的関数による計算結果であ明らかである（図11, 12).

\section{5. 結 言}

本報では購入された商品が逐次廃棄される場合に ついて, その商品の普及率の変化を解析した. 解析 を容易にするため廃棄の過程について 5 種のモデル を設定し，それぞれの場合について，その商品の所 有者数，単位時間当たりの購入者数，廃棄者数の間 の関係を表す数式を導いた．そしてこれらの数式を 解き，あるいは数值計算することにより，それぞれ の場合における普及・衰退過程の特徵を知ることが できた.

本研究では商品の所有者数, 購入者数および廃棄 者数などの変化を解析の対象としたが，これらはす べて人の数である. しかし実際に把握できるのは販 売された商品の数量であり，人の数ではない。した がって, 本研究の結果を実際に応用する場合には, 人の数を商品の数量に転換することが課題となる.

本報のモデルと理論式は衣料以外の商品にも適用 できる.

なお，本報の概要は平成 9 年度本学会年次大会で 報告した.

(注)

(9)式において $\alpha \leqq \beta$ とすると， $0<\alpha, 0<N(t), 0$ $<M$ であるから $\alpha N(t)\{(\alpha-\beta) M-\alpha N(t)\}<0$

$\therefore d N(t) / d t<0 \quad(0<t<\infty)$

すなわち $N(t)$ は発売当初より減少を続けること になる. したがって $N(t)$ の増加する過程は存在せ ず, 本研究の対象にはならない.

なお $\alpha=\beta$ の場合には(9)式は次のようになる. 

$\mathrm{d} N(t) / d t=-\alpha\{N(t)\}^{2}$
(a)
(e)式によれば, $N(t)$ は $N o$ より始まって次第に減 $\therefore d N(t) /\{N(t)\}^{2}=-\alpha d t$
(b) 少し, $t \rightarrow \infty$ で 0 になる.

両辺を積分すれば

$$
\begin{aligned}
& -1 / N(t)=-\alpha t+c . \\
& t=0 て ゙ N(t)=N_{o} \text { よって } c=-1 / N_{o} \\
& \text { (d)式を(c)式に代入して整理すれば } \\
& N(t)=1 /\left\{\alpha t+1 / N_{o}\right\}
\end{aligned}
$$

\section{参考文献}

(c) 1) 田畑昌顕；織機誌，49, T298 (1996)

(d)

(e)
2) T. Modis: "Predictions", Simon \& Schuster, (1992) モーディス著, 高橋秀明訳; “予測学入門”, 産能大学出版 部 (1994) 